Table 1. Pregnancy complications and outcomes according to the timing of discontinuation of BEL.

\begin{tabular}{|c|c|c|c|}
\hline & $\begin{array}{c}\text { BEL STOPPED } \\
\text { PRECONCEPTIONALLY } \\
\text { (2) }\end{array}$ & $\begin{array}{c}\text { BEL STOPPED AT } \\
\text { POS PREGNANCY } \\
\text { TEST (7) }\end{array}$ & $\begin{array}{l}\text { BEL STOPPED } \\
\text { DURING } \\
\text { PREGNANCY (4) }\end{array}$ \\
\hline Pre-eclampsia & $0 / 2$ & $0 / 7$ & $1 / 4(25 \%)$ \\
\hline Eclampsia & $0 / 2$ & $0 / 7$ & $1 / 4^{*}(25 \%)$ \\
\hline Gestational Diabetes & $0 / 2$ & $1 / 7(14 \%)$ & $0 / 4$ \\
\hline IUGR & $0 / 2$ & $1 / 7(14 \%)$ & $1 / 4^{\star}(25 \%)$ \\
\hline pPROM/PROM & $0 / 2$ & $0 / 7$ & $1 / 4(25 \%)$ \\
\hline Live birth & $1 / 2(50 \%)$ & $7 / 7$ (100\%) & $4 / 4$ (100\%) \\
\hline $\begin{array}{l}\text { Severe pre-term birth } \\
\left(\leq 34^{\text {th }} \text { week) }\right.\end{array}$ & $0 / 2$ & $0 / 7$ & $1 / 4^{*}(25 \%)$ \\
\hline $\begin{array}{l}\text { Late pre-term birth } \\
\left(35^{\text {th }}-37^{\text {th }} \text { week }\right)\end{array}$ & $0 / 2$ & $3 / 7(43 \%)$ & $0 / 4$ \\
\hline $\begin{array}{l}\text { Small for Gestational } \\
\text { age neonate }\end{array}$ & $0 / 2$ & $4 / 7(54 \%)$ & $1 / 4(25 \%)$ \\
\hline $\begin{array}{l}\text { Late miscarriage } \\
\left.\qquad>10^{\text {th }} \text { week }\right)\end{array}$ & $1 / 2(50 \%)$ & $0 / 7$ & $0 / 4$ \\
\hline Perinatal death & $0 / 2$ & $0 / 7$ & $1 / 4^{*}(25 \%)$ \\
\hline
\end{tabular}

IUGR: IntraUterine Growth Restriction; PROM: Premature Rupture of Membrane; pPROM: pretermPROM; ${ }^{*}$ in the same patient (history of thrombotic and obstetric-APS and lupus nephritis) who underwent Assisted Reproductive Technologies (embryo donation).

Eight newborns received vaccinations according to national schedule (missing data for 3 ). Five newborns were breastfed, 1 received formula milk and 5 mixed-feeding. BEL was resumed in $7 / 13$ patients after pregnancy (in 4 cases for flare), after a median period of 5 [4-22] months.

Conclusion: While more data are needed, this small series suggests that BEL might be a therapeutic option for SLE patients during pregnancy planning, similarly to other biological drugs used in chronic forms of arthritis.

Disclosure of Interests: None declared

DOI: 10.1136/annrheumdis-2021-eular.2862

\section{POS0703 CARDIAC ADVERSE EFFECTS OF LONG-TERM USE OF HYDROXYCHLOROQUINE IN SYSTEMIC LUPUS ERYTHEMATOSUS. SINGLE UNIVERSITY CENTER STUDY OF 109 PATIENTS}

A. Herrero-Morant ${ }^{1}$, A. Margarida-de Castro ${ }^{1}$, R. Pérez-Barquín ${ }^{1}$, J. ZubiaurZamacola ${ }^{1}$, M. Á. González-Gay ${ }^{1}$, R. Blanco ${ }^{1}$. ${ }^{1}$ Hospital Universitario Marqués de Valdecilla, Rheumatology and Cardiology, Santander, Spain

Background: Hydroxychloroquine (HCQ) is a widely used drug especially in connective tissue disorders such as Systemic Lupus Erythematosus (SLE). Cardiac adverse effects of long-term use of HCQ remains controversial.

Objectives: To assess cardiac adverse effects of long-term use of HCQ in SLE. Methods: Observational single center study of 109 patients with SLE treated with $\mathrm{HCQ}$ for more than 3 months. The main outcomes were cardiac structural and conduction disorders in a 12-lead electrocardiogram and/or echocardiogram at baseline and during HCQ treatment.

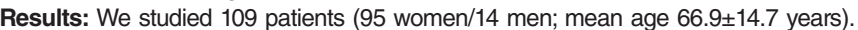
Main cardiovascular history was hypertension $(n=61,56.0 \%)$, diabetes mellitus $(n=16$, $14.7 \%)$ and renal impairment $(n=11,10.1 \%)$. HCQ was used for $11.7 \pm 8.9$ years. Initial median SLE Disease Activity Index 2000 (SLEDAI-2K) was 7 [3.75-11]. At baseline, 27 (24.8\%) patients had conduction disorders and $15(13.7 \%)$ had structural abnormalities: Most prevalent cardiac alterations were Left Anterior Fascicular Block (LAFB) $(n=9$, $8.3 \%)$, left ventricular hypertrophy $(n=9,8.3 \%)$ and right bundle branch block $(n=8$, $7.3 \%$ ). After $11.7 \pm 8.9$ years of follow-up (mean HCQ cumulative dose: $1042.2 \pm 267.5 \mathrm{~g}$; median SLEDAI-2K 1 [0-4]), there was a significant increase in conductions disorders $(n=41,37.6 \%, p=0.011)$ and in LAFB $(n=16,14.7 \%, p=0.021)$. There was no statistically significant increase in structural abnormalities $(n=21,19.7 \%, p=0.629)$.

Table 1. Main cardiac abnormalities at baseline and after follow-up.

\begin{tabular}{llll}
\hline & Baseline & After follow-up & $p$ \\
\hline Conduction disorders, $\mathrm{n}(\%)$ & $27(24.8)$ & $41(37.6)$ & 0.011 \\
Left anterior fascicular block & $9(8.3)$ & $16(14.7)$ & 0.021 \\
Right bundle branch block & $7(6.4)$ & $8(7.3)$ & 1.0 \\
Atrioventricular block & $4(3.6)$ & $11(10.1)$ & 0.092 \\
Incomplete right bundle branch block & $4(3.6)$ & $5(4.6)$ & 1.0 \\
Short PR interval & $2(1.8)$ & $4(3.7)$ & 0.5 \\
Prolonged QT corrected interval & $2(1.8)$ & $4(3.7)$ & 0.625 \\
Left bundle branch block & $1(0.9)$ & $5(4.6)$ & 0.125 \\
Atrial Fibrillation & $1(0.9)$ & $5(4.6)$ & 0.219 \\
Structural abnormalities, $\mathrm{n}(\%)$ & $15(13.7)$ & $21(19.7)$ & 0.629 \\
Ventricular hypertrophy & $9(8.3)$ & $9(8.3)$ & 1.0 \\
Atrial enlargement & $6(5.5)$ & $13(11.9)$ & 0.096 \\
& & &
\end{tabular}

Main cardiac abnormalities at baseline and after $11.7 \pm 8.9$ years of follow-up are summarized in Table 1. Time of occurrence of cardiac adverse effect in relation to $\mathrm{HCQ}$ cumulative dose is shown in Figure 1.

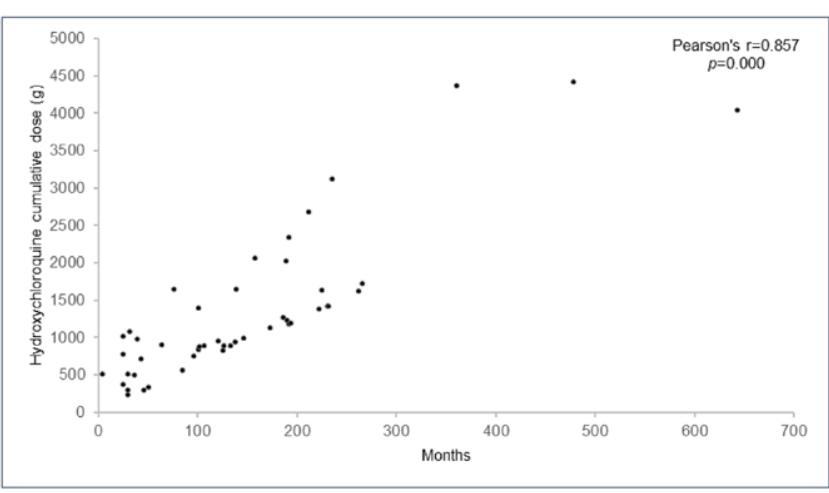

Figure 1. Time of occurrence of cardiac adverse effect in relation to hydroxychloroquine cumulative dose.

Conclusion: Conduction disorders were more prevalent than structural abnormalities. Patients with SLE treated with HCQ had a significant increase in LAFB. Use of electrocardiogram and/or echocardiogram may be helpful in monitoring cardiac adverse effects.

Disclosure of Interests: Alba Herrero-Morant: None declared, Adrián Margarida-de Castro: None declared, Raquel Pérez-Barquín: None declared, Jon Zubiaur-Zamacola: None declared, Miguel Á. González-Gay Speakers bureau: AbbVie, Pfizer, Roche, Sanofi, Lilly, Celgene and MSD, Grant/research support from: AbbVie, MSD, Jansen and Roche, Ricardo Blanco Speakers bureau: AbbVie, Pfizer, Roche, Bristol-Myers, Janssen, Sanofi, Lilly and MSD, Grant/research support from: AbbVie, MSD, and Roche DOI: 10.1136/annrheumdis-2021-eular.3471

\section{POS0704 LONG-TERM CLINICAL OUTCOMES OF PATIENTS WITH LUPUS NEPHRITIS TREATED WITH AN INTENSIFIED B-CELL DEPLETION PROTOCOL: A PROSPECTIVE STUDY}

D. Roccatello ${ }^{1}$, S. Sciascia ${ }^{1}$, C. Naretto ${ }^{1}$, M. Alpa ${ }^{1}$, R. Fenoglio ${ }^{1}$, M. Ferro ${ }^{1}$, G. Quattrocchio ${ }^{1}$, E. Rubini', E. Rahbari ${ }^{1}$, D. Rossi ${ }^{1} .{ }^{1}$ University of Torino, Department of Clinical and Biological Sciences, Turin, Italy

Background: B cells play a key role In the pathogenesis of Lupus Nephritis (LN). Objectives: we aim to investigate the safety and efficacy of an intensified B-cell depletion induction therapy (IBCDT) without immunosuppressive maintenance regimen compared to standard of care in biopsy-proven LN.

Methods: Thirty patients were administered an IBCDT (4 weekly Rituximab $375 \mathrm{mg} / \mathrm{m} 2$ and 2 more doses after $1 \& 2$ months; 2 infusions of $10 \mathrm{mg} / \mathrm{kg}$ cyclophosphamide (CYC), 3 methylprednisolone pulses), followed by oral prednisone (tapered to $5 \mathrm{mg} /$ day by the $3 \mathrm{rd}$ month). No immunosuppressive maintenance therapy was given. Thirty patients matched for $L N$ class and age were selected as controls: 20 received 3 methylprednisolone pulses days followed by oral prednisone and mycophenolate mofetil (MMF) 2-3g/day, while 10 were given the Euro Lupus CYC.

Results: At 12 months, complete renal remission was observed in $93 \%$ of patients on IBCDT, in $62.7 \%$ on MMF, and in $75 \%$ on CYC ( $p=0,03)$; the dose of oral prednisone was lower in the IBCDT group (mean \pm SD $2.9 \pm 5.0 \mathrm{mg} / \mathrm{dl}$ ) than MMF $(10.5 \pm 8.0 \mathrm{mg} /$ day, $<<0.01)$ or $\mathrm{CYC}$ group $(7.5 \pm 9.0 \mathrm{mg} /$ day, $\mathrm{p}<0.01)$. Mean follow-up after treatment was 44.5 months (IQR 36-120months), 48.6 months (IQR36-120months), and 45.3 (IQR36-120months) for IBCDT, MMF and CYC, respectively. At their last follow-up visit, we observed no significant differences in proteinuria and serum creatinine, nor in the frequency of new flares among the three groups.

Conclusion: In biopsy proven LN, the IBCDT without further immunosuppressive maintenance therapy was shown to be as effective as conventional regimen of MMF or CYC followed by a 3-year maintenance MMF regimen. Moreover, the use of IBCDT was associated with a marked reduction of glucocorticoid cumulative dose.

Disclosure of Interests: None declared

DOI: 10.1136/annrheumdis-2021-eular.3803 